The Brock Review Volume 12 No. 1 (2011)

(C) Brock University

\title{
Animal Liberation: A View from Political Science
}

Paul Hamilton

\begin{abstract}
Political science has tended not to problematize human domination over nonhuman animals. Political scientists have been engaged intellectually and politically with other struggles for justice and citizenship leading one to question the apparent indifference to the issue of 'animal rights'. This paper accounts for the absence of animals in political science research and suggests that recent scholarship has begun to take animal liberation seriously. The paper then looks at the options for the broader animal liberation movement and suggests that incremental change is the best and only option for animal advocates in contemporary liberal democracies.
\end{abstract}

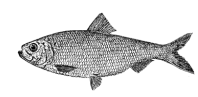

Academic interest in "animal rights" has grown in the last decade. Prominent philosophers like Martha Nussbaum have written on this subject and university websites now feature programs and institutes dedicated to the study of animals, not merely from a biological perspective, but from many academic disciplines in the humanities and social sciences. ${ }^{1}$ This interest is noteworthy because it often seeks to understand animals as subjects rather than objects, or means to an end. Animals are not bystanders, or "extras" in this growing body of work, but constitute leading and central roles. Animals are "problematized;" they are seen as indispensable actors in human culture and art. Their presence is no longer taken for granted.

Moreover, much of this scholarly interest parallels a broader corresponding growth in support for "animal welfare" and "animal rights," terms that often provoke debate and discussion about the contested nature of these terms. In this paper, I intend to consider animals from the perspective of a comparative political scientist and locate animals in political science (or rather, fail to locate them). I will also consider one of the central debates within the contemporary animal liberation movement, which is usually presented as a dichotomy (a false one, I believe) pitting "rights" for animals versus animal "welfare." 
If animals are becoming salient subjects in the fields of law, sociology, and philosophy, they continue, for the most part, to be invisible in political science. ${ }^{2}$ Animals, to the extent they are mentioned at all, are denigrated implicitly when negatively contrasted with humans who are uniquely endowed with qualities of reason and deliberation. The foundation of political science-the subfield of political theory/philosophy-is concerned with core principles of justice and equality. Foundational works deliberate on the core questions of politics within an explicitly normative framework. One sees references to animals on occasion but these are almost entirely used to illustrate the qualities that make human unique among all life on Earth and implicitly assume human domination. In Hobbes' account of the state of nature, humans behave like beasts: they live lives that are famously "nasty, brutish, and short." ${ }^{3}$ Aristotle claims that humans are political animals and this ability creates a gaping chasm separating animal life from humanity. Rousseau sees humans in the state of nature as animal-like in the sense of being innocent, uncorrupted by modernity and market relations, and yet this comparison underlines the diminished capacities of animals vis-a-vis humanity. ${ }^{4}$

It would be a mistake to ignore those political theorists who have at least raised the moral and political status of animals in their work. Alasdair Cochrane observes that: "Quite simply, most political theorists have said, and continue to say, almost nothing on what political communities owe to animals. Indeed, when one looks back over the history of political thought, this silence is particularly striking." 5 There are, as Cochrane notes, important exceptions to this. Ancient philosophers like Plutarch criticized the eating of animals and modern utilitarians like Bentham explicitly argue for taking animals' interests into consideration. ${ }^{6}$ Garner has also written a great deal about political theory and the politics of animal rights and points to political theorists such as Nozick, who have at least given consideration to the moral-political status of animals. ${ }^{7}$ John Rawls, who excluded animals from moral consideration in $A$ Theory of Justice, at least confronts the issue. ${ }^{8}$

We might also observe that political philosophers have excluded other humans from consideration as "citizens." But while later philosophers eloquently advanced a conception of universal human equality, there is precious little interest in the nature of animals and the question of morality as concerning human-animal interactions. The development of science and the advances in biology, for example, have produced a very different worldview among academic scientists. Instead of exalting humans and diminishing animals, we see an interesting tendency to diminish human 
distinctiveness and instead place humans on a developmental continuum. Life is neither "lower" nor "higher" but more complex or less complex. Humans are another product of evolution.

The nature of political science or even social science generally, means that the subject matter is not rule governed and debates are not ever wholly won or lost. Theories are not replaced, but rather accumulate over time. No single paradigm governs the fields. This is particularly true in political science where empirical study is often explicitly or implicitly normative. Bias is formalized in theories (Marxism or Rational Choice, for example) or implicit in the premises of research. Unlike science which has something like a central dogma (Laws of thermodynamics, DNA, or evolutionary theory) political science has very little theoretical or methodological unity.

While scientific discovery has forced humanity to at least contemplate a diminished position for humans in the cosmological hierarchy, research in social science remains concerned centrally with humans. This has led to an absent actor central to human affairs: the animal. There is no society I am aware of that does not subjugate animals, and this hierarchy is reflected in intellectual inquiry about human society. I should note that science's advances have not necessarily been beneficial for animals. The humbling of humanity accomplished in part by Copernicus and Darwin has not reduced the use of animals in scientific and medical research. In fact, more animals are used in scientific research on the planet today than at any other time in history.

Political science, while founded upon the classic works of political philosophers, is also a relatively new, empirically-based discipline. The fields of comparative politics, international relations, public administration and others seek to understand political phenomena. The vastness of the discipline is astonishing as is the theoretical and methodological breadth. Yet for the most part, precious little attention is paid to the other sentient beings that are central to the economic and social fabric of human societies.

At its core this absence must stem from a denial of animal subjecthood. Animals are routinely denigrated as diminished beings incapable of higher functions such as thoughtful deliberation or reflection. There is a remarkable lack of understanding of animals or even curiosity about them. They are, at some remove, discussed as a collective in work on environmental politics and policy. But there is no sense that animals constitute a category of sentient agents with interests and preferences, something assumed by natural scientists. In fact, whole subfields of biology (e.g. ethology) would be incomprehensible without a theory of animals as agents. 
For political scientists, the challenge is formidable. Animals may be political, in the sense that there are power relations and hierarchies in nature, but they do not have the capacity to participate in human political life. They may be the subjects of political debate, but they do not act collectively or individually in politics. This is the core problem: How can one incorporate sentient beings into a theory of politics which cannot see them as political actors?

Some precedent may be seen in the way that corporations have acquired legal and political personalities. Of course, corporations are human artefacts and are not sentient, but they have been partly integrated in political life. Might animals be granted a status that recognizes their vital interests without any expectation of something like political citizenship? Recent efforts to endow the great apes with rights have some support though little concrete success as of yet. Still, this might point the way to a political theory that can incorporate animals within existing legal- political structures.

\section{Animals welfare and animal rights}

Within the broader animal liberation movement, there is great diversity of perspectives and strategies for reducing animal exploitation and abuse. One area of great debate is posed as a dichotomy between the proponents of animal welfare and those supporting animal rights. The "animal rights" perspective is much newer and associated with the work of philosophers like Tom Regan. For animal rights activists, the solution is, as the slogan says, "empty cages not bigger cages." Animal rights activists often see their struggle as akin to those for civil rights. The central problem is speciesism, a phenomenon akin to racism and sexism that must be eradicated to free animals from exploitation.

The older and well-institutionalized perspective is often referred to as animal welfare. Derided by animal rights activists, supporters of animal welfare seek compromise, incremental reductions in the most obvious and cruel forms of animal exploitation without imposing a major revolution in human relations with animals. Animal welfare views have probably been around as long as humans and animals have interacted but were institutionalized, with royal aid, in countries like Britain. The animal welfare approach was most concerned with animals used in public (draught animals), and pets. Often, welfare organizations have become incorporated in the larger political system as charities, thereby losing much of their political voice, in exchange for tax-exempt status and the imprimatur of the state. Animal welfare approaches do not seek to end animal exploitation as 
animal rights activists do, but rather seek to regulate and reduce cruelty, especially concerning traditional pets.

The debate between these broad groups is evident at the grass roots level of animal activism. So often, welfarists are derided by animal rights activists for their apparent cosmetic and selective concern with certain animals. Welfarists see animal rights activists as utopian and impractical. It may be a sign of the vigour and maturity of a movement that such debates exist at all, but I think a political scientist can make some observations about this false dichotomy that can moderate the tone of the debate and open the opportunity for dialogue.

It is vital to acknowledge the crude nature of the dichotomy laid out above. Peter Singer, typically regarded as a leader of the animal rights movement, does not endorse the term "rights" at all. ${ }^{9}$ For Singer, the preferred ethical system for addressing animal exploitation is utilitarianism, which, distilled to its essence, involves the equal weighing of interests, with animals vital interests outweighing human desires to eat or experiment on them. Casual observers mistakenly cite Singer among the leading figure of the "animal rights" movement, which reinforces and widens the welfarerights dichotomy.

Within the "welfare" community there is great diversity. In fact, there is little community to speak of. Many animal welfare actors are charitable institutions run like small corporations. Others are locally based and operated by a few volunteers. Many are tightly circumscribed and deal only with specific dog breeds or species.

The debate between the two perspectives is typically confined to elite participant observers who focus on the merits and strategies of the perspectives. The debate reminds one of the fractious debates that emerged with the evolution of Marxism in the late $19^{\text {th }}$ century and beyond. The debate is often conducted in a way that reveals little familiarity with the work of public policy analysts or historians of social movements. For a political scientist, many of the prescriptions to animal exploitation seem, frankly, fanciful.

Abolitionists-those who support personhood for animals—are scornful of half-measures, of incrementalism. Rather than reducing suffering, incremental and piecemeal efforts to end some particularly egregious practice effectively endorses other forms of animal exploitation. By introducing a law, for example, that bans the use of veal crates, or the production of foie gras, the public is allowed to believe that other, routine uses of animals are acceptable. Efforts to ban the Canadian commercial 
seal hunt are ephemeral when compared to the suffering of billions of animals raised for food and distract from the primary activity that inflicts suffering on animals: modern industrial production.

What insights does political science have to offer those deliberating about strategies for ending animal exploitation? The first observation that comes to mind is the uneven distribution of animal rights activities around the globe. If the aim is complete abolition of animal exploitation, then the activist must confront some important facts. Animal activism is most visible in democratic societies. These are also among the worst offenders when it comes to both suffering and numbers of animals used. However, interest groups activity to end animal exploitation can only occur in democratic states. We know that democracies outperform all other current and historical regime types in human welfare standards, environmental protection, and animal protection. This, of course, is relative. Non-democratic societies lack a free press, a vigorous civil society, and contested elections between genuinely distinct political parties. In societies that lack these qualities, animal rights are unlikely to be achieved. That means, for now, that only in democratic states will personhood for animals be possible.

Some abolitionists seem to believe that animal rights or personhood is only a law away. Pass a law and the rest will follow. The problem with this view is that it is naive and gives the judicial institutions of government an astonishing and unrealistic degree of autonomy from society. Laws do change and the history of public law in the United States demonstrates a remarkable ability to push majorities to respect the interests of minorities. The 1954 Brown v. Topeka Board of Education was a watershed judicial decision that broke with a 60 year old judicial consensus on the acceptability of school segregation. Before Brown, Plessy v. Ferguson established the 'separate but equal' doctrine and this guided thinking about school segregation for decades. The Brown decision reflected a variety of factors: social change, change in the composition of the Supreme Court, and very importantly, the insights of social science research on the impact of segregation on minority children. These variables permitted the court to break with precedent and strike down segregation in US schools.

What legalistic strategies fail to consider is that the judicial branch's decisions are shaped by social mores, common law precedent and the biases of individual justices. Moreover, the courts are bound to interpret the constitution that is the product of centuries-old deliberations about the guiding principles of society. Enacting a law that banned the eating of meat would quickly be met with appeals that would argue that the constitution protects the right of people to eat what they wish. Any effort to change the constitution to change the legal status of animals would require a 
constitutional amendment. ${ }^{10}$ In the United States, for example, most constitutional amendments require the consent of three-quarters of state legislatures and two-thirds of Congress with a set time frame. The fact that only seventeen amendments have passed since 1781 is testament to the difficulty of passing such amendments.

When one looks at the struggle for citizenship that took place in the US over the last two centuries it is clear that rights are the product of sustained and uneven struggle. In some cases, watershed moments ended institutionally embedded practices like slavery. But the end of slavery was not brought about by an act of Congress or the Supreme Court. The institution of slavery only ended with a protracted war that led to the death of 600,000 people and the destruction of a socioeconomic system. Full citizenship for women, in the sense of voting and property rights, did not emerge in a single moment but over time. Full citizenship for African-Americans did not come formally until the 1964 Civil Rights Act, but even after this historical moment laws remained barring marriage between "races." 11

More recently, gays and lesbians have won certain rights such as the right to marry in countries like Canada, Argentina and Spain. In the US gays and lesbians have marriage rights in some states but not in most. The decision to permit gay marriage in Canada was preceded by other important milestones including the decriminalization of homosexuality by Pierre Trudeau when serving as Justice Minister. The decision to exclude homosexuality from the diagnostic manual of mental disorders is also a relatively recent event.

What is clear from the citizenship struggles of the past two centuries is that multiple actors with different strategies sought different goals but the synthesis of these activities contributed to the formal achievement of citizenship for women, African-Americans and gays/lesbians. Feminists have sued to courts to move their agenda but they have also used art, culture, and social institutions to press the cause of women. Most importantly, in each case touched on, the oppressed themselves contributed to their own liberation. Former slaves toured Europe and the Northern US telling their stories. African-Americans were central in the movement to gain full citizenship rights in the $20^{\text {th }}$ century. Gays used the courts and movement politics to change attitudes and laws. The core difference between the movements for women's rights, for example, and animal rights, is that the subjects of the animal rights movement have very limited means to advancing their interests collectively. One might think that campaigns to gain rights for children, or to protect them from sexual abuse or labour, would be analogous, but most children mature and acquire voice and 
autonomy. Animals that are part of the human economic/social system have little realistic chance of escape from their bondage nor can they eventually acquire the skills and attributes that would make them autonomous participants in their own struggle.

If the animal liberation movement is to be the moral cause of the $21^{\text {st }}$ century, it must find a way to assert the interests of non-humans, beings that one can only imperfectly, if ever, fully understand. One cannot directly experience what it is like to be an elephant in a circus and no elephant will write an account of her experiences in one.

When trying to explain political phenomena, political scientists often talk about political culture, the set of attitudes and behaviours that societies hold regarding authority and politics. In "rights" cultures such as those of Western Europe and North America, a rights discourse is familiar and well established. Appeals to one's rights are powerful and frequent in political life and this has helped shape the contemporary animal rights movement, even if influential advocates of animal liberation like Singer do not advocate rights as all.

The domination of animals by humans is made possible not only by law, but by dominant and rarely questioned assumptions about animals found in almost every culture. The concept of dominion in the Christian Bible sees humans as stewards of all creation. From this premise, human exploitation is often justified. Religion has often been used to defend domination as seen in the case of slavery and apartheid in South Africa. So powerful is the concept of "dominion" that its assumptions are widely shared even among the casually religious. Religion joins past practice and economic rationale to justify the exploitation of animals. We can see the impact of religion in judicial deliberations. The US Supreme Court has upheld the right of Santeria practitioners to sacrifice animals in rituals. ${ }^{12}$ The First Amendment protection for religious practice is a powerful defence of religious practices even when they compromise the fundamental interests of animals. So central are various creation myths establishing the supremacy of humans over nature, that any effort to amend or revise the hierarchy is seen as heretical and threatening to entire cosmologies. This is particularly true with the Abrahamic traditions (Judaism, Christianity, and Islam) that are the nominal faiths of about one-third of the planet's population.

The cultural assumptions of human dominance are rooted in religion and transmitted via agents of socialization. Media, family, civil society, religious institutions, the education system and law all reinforce human exploitation. From early childhood children are taught to hunt and fish, eat meat, attend circuses and zoos, have pets, dissect animals in school, and otherwise internalize 
speciesist norms. From a Gramscian perspective, the task is to create a counterhegemonic narrative that can challenge the existing hegemony of humans. ${ }^{13}$ This is fairly easy to contemplate, but harder to implement.

Culture is a powerful shaper of human behaviour and the multiple reinforcing mechanisms for imputing culture make it difficult to change. Religious rites reinforce the eating of meat, complete with detailed methods of slaughter. In the face of animal rights' arguments, many people confront a psychological challenge to almost primordial beliefs. This is stressful and threatening, and cultural norms are fallen back on to justify animal exploitation. Culture also permeates institutions such as the judicial system, which denies personhood to animals, and the education system which presents a human centred world to children, if only implicitly. There is rarely a choice involved in becoming part of speciesist society; one simply absorbs dominant unspoken norms. Questioning fundamental norms and practices, and then reorienting one's behaviour accordingly brings serious psychological and social costs. One may find oneself isolated or shunned by one's family or community. These are powerful counter incentives that allow dominant norms to exert control and reproduce themselves.

Yet another barrier to a fundamental change to animals' status is economic. There is an astonishing degree of integration of animals in most human societies. Animals and their bodies are found in many commodities. Animals in enormous numbers are used in education and science. Billions of animals are raised for human consumption, a number that will grow exponentially with the economic growth of the developing world. ${ }^{14}$ Many millions of other animals are hunted, imprisoned in zoos and circuses, killed for their fur, and otherwise subjected to human domination. All of these activities provide enormous economic benefit to individuals as well as society as a whole. This creates a powerful inertia against fundamental change to human-animal relations. Not only do most people benefit from animal exploitation, but also organized interests eagerly use their economic and political power to maintain the status quo. Against this we have piecemeal and loosely organized interest groups. The animal industrial complex is the sum total of individuals and industries that enthusiastically and effectively guard human domination.

From a political science perspective, no analysis of the human-animal hierarchy is complete without considering some fundamental actors in democratic political systems. Interests groups, social movements, political parties and bureaucracies are vital actors in public policy. In the 1950s American political scientists idealized a political system with competing interest groups seeking to influence elected officials and the policy they produced. We know now, of course, the interest groups 
and social movements vary considerable in their relative power and influence. Organized interests exert enormous influence on policy especially when the policy area is highly technical or functionally circumscribed. Many variables influence the manner and degree to which influence is applied, but there is no doubt that the vast weight of resources of interests opposed to animal liberation is enormous.

Analysts of interest groups have long recognized that interests groups vary enormously in their relative power. Business interests have great resources that can be directed to influence campaign financing, fund advertising directed at society and lobby for particular policy preferences. Animal welfare and liberation groups are tiny in comparison to the major animal industries (agriculture and research). As such there is a clear asymmetry in power and this further underscores how difficult animal liberation will be. Still, in the face of enormous popular mobilization, animal welfare advocates have scored important victories, albeit ones that only reduce, rather than eliminate animal suffering. Recent initiatives at the state level in the United States are great examples of incremental change driven by successful mobilization of scarce resources and public sympathy. ${ }^{15}$

Another obstacle to fundamental change in the human-animal relationship is the absence of political parties championing the cause. No mainstream political party of any substantial size champions the rights of animals. Some parties are more progressive than others but basic assumptions about the subordination of animal interests to human ones remain. Green parties are very concerned with bio-communities and ecosystems; they are less concerned with the individual components of these communities. Most party systems in the democracies reflect enduring social divisions or cleavages. These may be of a class, ethnic, or regional nature. At the moment, a cleavage on the issue of animal liberation seems unlikely.

Social movements may have important impacts on politics and policy. One need only look at the rise in environmental consciousness that has emerged in recent decades as an example. Similar change seems driven by the feminist and civil rights movements of the last few decades. The animal rights movement is gaining in power and confidence but remains less institutionalized and organized than these other predecessors. Part of the problem is the nature of the animal liberation movement. I turn now to an analysis of this movement and how I think gains for animal liberation will likely be made in the future. 


\section{Attaining Animal Liberation}

One weakness of social movements in influencing politics is their decentralized structure and the general nature of the demands. A great example would be the "peace movement." No single politician or government can deliver on a demand for peace and so the movement has few victories to point to. Idealists may campaign for world peace but will never win it. Pragmatists who labour on a particular policy front (landmines) may win a great victory for human welfare but may sully themselves in the eyes of idealists for accepting flawed agreements and working with sovereign states. ${ }^{16}$ Social movements are hampered in their efforts because progress requires compromise, organizational hierarchy and role assignments-often the very qualities that social movement supporters abhor.

Interests groups (humane societies, breed-specific rescue organizations) have had an important impact on establishing minimal welfare standards for animals in many Western democracies. Interest groups tend to have greater resources than social movements and tend to be enduring and institutionalized. These strengths are accompanied by their cooptation by the state. In most countries, charities are precluded from lobbying politicians or publically taking a partisan stance during elections. But, charitable status can endow organizations with legitimacy and provide incentives (tax deductions) to donors. The decision to seek charitable status may have the consequence of reducing animal protection groups' radicalism.

More radical organizations may be freer to speak and act, but have fewer resources for advancing their cause. A parallel is seen in the ecology movement after WWII that, in Europe, was a social movement, but eventually institutionalized in Green parties and powerful interest groups like the UK's Campaign for Nuclear Disarmament. The "animal rights" movement is similarly diverse in structure, form strategies and objectives. As Munro observes, both animal interest groups and less organized "movements" use a variety of methods to advance their cause including persuasion, protest, engaging in civil disobedience, conducting investigations and legal challenges to animal abuse. $^{17}$

Within the animal liberation movements there is a continuum of strategies and goals. Idealists decry anything short of complete abolition of the use of animals. They often are scornful of narrower campaigns (say, against the seal hunt) or incremental change. Abolitionists critique those 
who seek to stop particularly cruel practices (veal crates) because these implicitly communicate that animal exploitation in general is acceptable. One gets the impression that incremental reform is actually contrary to the interests of animals. This uncompromising stance is commonly found among animal activists.

There is an interesting similarity between the animal liberation movement and Marxism. Marxism was a product of the philosophical and socio-economic analyses of Karl Marx. It informed a variety of political movements which continue to this day. Marxists, convinced that they had discovered a fundamental law of social change, sometimes scorned efforts by social democrats to alleviate the worst aspects of working class deprivation. In fact, Marxists were alarmed that early welfare state initiatives like those initiated by Bismarck in the early $20^{\text {th }}$ century would delay the inevitable revolt of the proletariat. This analysis can be seen in Marx's Critique of the Gotha program. ${ }^{18}$

\section{Conclusion}

This essay began by noting the near absence of animal subjects in political science. Fortunately, this absence is being addressed with new scholarship taking animal welfare seriously. ${ }^{19}$ This attention is also noted in other fields like law and sociology. This is encouraging and mirrors a broad social movement that questions the status quo regarding animal subordination. Also encouraging is the diversity of approaches taken by scholars interested in the problem of animalhuman relations.

Proponents of animal liberation should take heart from this intellectual trend. As the profile of animals is enhanced, animal welfare issues will be come increasingly mainstream and compelling to policy makers, voters, mass media and the public at large. Still, fundamental challenges remain. Animals cannot, collectively, attain their own liberation. They cannot "speak" for themselves in the way that human minorities and oppressed groups have/were able to. It will be up to their human allies to articulate and press for policies that reduce animal suffering and constantly renegotiate the terms of animal subordination. This need not be a collaborationist "welfarism" defined by "bigger cages." On the contrary, it means creating the conditions for fundamental alterations of consciousness and the development of new and enduring norms of behaviour. Reform is not the end of the dialogue but the beginning. Politics is about compromise, negotiation and evolution of norms 
in response to new social and cultural mores. The battles to end slavery and the oppression of women and minorities are not yet finished. Much remains to be done to protect children, to stop human trafficking, to guarantee basic human rights and spread democracy. We do not, I am sure, assume that any particular remedy to any particular human rights violation is the end of the road. Why would we accept the same logic for animals? Future generations will also consider these questions in light of what previous generations have accomplished and tackle these issues in their own way. No movement for human emancipation has ever been won in a moment. Slavery ended at very different times but, in insidious ways, continues to this day. But earlier milestones in the struggle against human bondage were critical to get humanity to where it is today.

The case for animal liberations is made loudly and persuasively today. The animal liberation movements can take heart in the fact that it has at its disposal powerful tools unavailable to previous movements. Mass media, the Internet, social media and international regulatory regimes all have a vital role to play in pushing the animal agenda. The possibilities for local and international organization are vast and young people seem more interested in these issues than ever before. Important victories inspire those who have struggled for so long. The recent banning of seal products by the European Union is a great example of the power of international organizations. Animal activists have a wide array of tools to use to press their case and while the struggle is global, the real work will be local. Everywhere civil society is allowed to flourish animal activists are winning victories in their communities.

The argument juxtaposing instrumentalism and abolitionism is empty. There will be no single moment of liberation but many, many moments which will lead, ultimately, to a new morality which will benefit humans as much as animals. Much of this essay outlined the powerful forces that benefit from the status quo but we know that moments of punctuated equilibrium can also occur when a constellation of factors align and a new normal can emerge. My point is that we will not likely know precisely when this moment will arrive. The task of animal activists will be to work within every institution of society to push the animal liberation agenda until the dam breaks.

\section{Notes}

${ }^{1}$ Martha Nussbaum, "Beyond "Compassion and Humanity": Justice for Nonhuman Animals" in Animal Rights: Current Debates and New Directions, ed. Cass R. Sunstein and Martha Nussbaum (New York, NY: Oxford U. Press, 2004), $299-320$. 
2 There is a growing interest in animals in the study of law, evidenced in the establishment of animal related institutes in schools such as Duke University. A growing body of legal scholarship is taking animals seriously. See Taimie Bryant "Similarity or Difference as a Basis for Justice: Must Animals be Like Humans to be Legally Protected from Humans? Law and Contemporary Problems Vol. 70, 206-254; Jeff Welty "Humane Slaughter Laws" Law and Contemporary Problems, Vol. 70 , pp. 175-206. In sociology, animals have become the subject of scholarly consideration. See Bill Winders and Dave Nibert, "Consuming the Surplus: Expanding "Meat" Consumption and Animal Oppression" International Journal of Sociology and Social Policy Vol. 24: 9, 2004, pp. 76-96.; John Sorenson About Canada: Animal Rights (Winnipeg: Fernwood Publishing, 2010).

3 Thomas Hobbes, Leviathan ed. C.B. Macpherson (Harmondsworth: Penguin English Library, 1981), pp. 185-6.

${ }^{4}$ Jean-Jacques Rousseau, On the Social Contract, (Indianapolis: Hacket Publishing Company 1987).

${ }^{5}$ Alisdair Cochrane, An Introduction to Animals and Political Theory (Basinstoke: Palgrave Macmillan, 2010$)$ p. 4.

6 Ibid, p. 6.

${ }^{7}$ Robert Garner, "The Politics of Animal Rights" British Politics 2008, 3, p. 111. See also Animals, Politics and Morality, 2nd ed. (Manchester: Manchester University Press) and Political Animals: Animal Protection Politics in Britain and the United States (Basingstoke: Macmillan)

${ }^{8}$ John Rawls, A Theory of Justice, (Oxford: Oxford University Press, 1972).

9 Peter Singer, Animal Liberation 2nd ed. (NY: New York Review of Book, 1990s).

10 A number of countries have language in their constitutions that suggest an obligation to protect a state's ecology (Bolivia, for example). What such general language actually means for human-animal relations is unclear and as yet untested.

11 The Supreme Court of the United States struck down Virginia's miscegenation law in 1967 (Loving v. Virginia).

${ }^{12}$ Church of Lukumi Babalu Aye v. City of Hialeah (1993). The Supreme Court decided that Hialeah, Florida's laws banning animal sacrifice targeted practitioners of Santeria selectively and therefore violated the $1^{\text {st }}$ amendment protections for religious worship.

13 Antonio Gramsci Letters From Prison (New York: Columbia University Press, 1994)

14 Between the early 1960s and 2005, the consumption of animal products has increased considerably. A report by the Food and Agricultural Organization of the United Nations observes that "consumption of milk per capita has almost doubled, meat consumption more than tripled and egg consumption increased by a factor of five" (UN Food and Agricultural Organization, 2009, 9). It is predicted that meat consumption will increase globally between 2000-2050. For example, in East and South Asia and the Pacific, meat consumption in kilograms per capita was twenty-eight in 2000 , but this will increase to 51 kilograms by 2050. This is a consequence of rapid economic growth, especially in China and other parts of Asia.

15 Activists obtained 500,000 signatures in Ohio this year to get a ballot initiative on the 2010 midterm congressional ballot. The ballot initiative was forestalled when Governor Strickland presided over a deal that would bring important welfare changes to agriculture in Ohio. See http://farmsanctuary.typepad.com/making_hay/2010/07/importantprogress-for-farm-animals-in-ohio.html. Governor Schwarzenegger signed a bill into law in July 2010 that would ban the production of eggs in California from facilities that did not allow hens to fully stretch their bodies. This bill's impact is important because California is a net importer of eggs. Suppliers from outside the state will have to comply with this law. Last year, Port Colborne, Ontario enacted a policy that would require municipal facilities to use free-range eggs. Local government can have an important role in reducing animal suffering.

${ }^{16}$ The 1999 Ottawa Treaty banning the production and sale of landmines was the culmination of efforts by NGOs to ban these diabolical weapons. It is an imperfect treaty because major powers like China, Russia and the USA have not signed, but the treaty has produced tangible results. A number of previously mine-plagued states (like Rwanda) are now mine free and none of this would have taken place had the initial organizers opted for purity over pragmatism.

${ }^{17}$ Lyle Munro, "Strategies, Action Repertoires and DIY Activism in the Animal Rights Movement" Social Movement Studies Vol. 4:1 2005, p. 78.

${ }^{18}$ Karl Marx, Critique of the Gotha Program, in David McLellan ed. Karl Marx: Selected Writings (NY: Oxford U. Press), 564570 .

${ }^{19}$ For a political economy perspective see Bob Torres. Making a Killing: The Political Economy of Animal Rights Oakland, CA: AK Press, 2007.There is a growing scholarship comparing the successes of animals rights in various jurisdictions see Martin Balluch, "How Austria Achieved a Historic Breakthrough for Animals" In In Defense of Animals: The Second Wave, ed. Peter Singer, 157-166. Malden, MA: Blackwell Publishing, 2006. ;( Evans, Erin. "Constitutional Inclusion of Animal Rights in Germany and Switzerland: How Did Animal Protection Become an Issue of National Importance?” Society and Animals 18 (2010): 231-250. 


\section{Bibliography}

Balluch, Martin, "How Austria Achieved a Historic Breakthrough for Animals," in In Defense of Animals: The Second Wave, ed. Peter Singer, 157-166. Malden, MA: Blackwell Publishing, 2006.

Bryant, Taimie. "Similarity or Difference as a Basis for Justice: Must Animals be Like Humans to be Legally Protected from Humans?" Law and Contemporary Problems 70 (2007): 206-254.

Cochrane, Alisdair. An Introduction to Animals and Political Theory. Basingstoke: Palgrave Macmillan, 2010.

Evans, Erin. "Constitutional Inclusion of Animal Rights in Germany and Switzerland: How Did Animal Protection Become an Issue of National Importance?” Society and Animals 18 (2010): 231-250.

Garner, Robert. “The Politics of Animal Rights” British Politics 3 (2008): 110-119.

---. Animals, Politics and Morality, $2^{\text {nd }}$ ed. Manchester: Manchester University Press, 2004.

---. Political Animals: Animal Protection Politics in Britain and the United States. Basingstoke: Macmillan, 1998.

Gramsci, Antonio. Letters From Prison. New York: Columbia University Press, 1994.

Hobbes, Thomas. Leviathan, ed. C.B. Macpherson, Harmondsworth: Penguin English Library, 1981.

Nussbaum, Martha C. "Beyond "Compassion and Humanity": Justice for Nonhuman Animals" In Animal Rights: Current Debates and New Directions, ed. Cass R. Sunstein and Martha C. Nussbaum, 299-320. New York: Oxford University Press, 2004.

Marx, Karl. "Critique of the Gotha Program.” In Karl Marx: Selected Writings, edited by David McLellan, 564-570. NY: Oxford U. Press, 1977.

Munro, Lyle. "Strategies, Action Repertoires and DIY Activism in the Animal Rights Movement." Social Movement Studies 4 (2005) : 75-94.

Rawls, John. A Theory of Justice. Oxford: Oxford University Press, 1972.

Regan, Tom. The Case for Animal Rights. NY: Routledge, 2008.

Rousseau, Jean-Jacques. On the Social Contract. Indianapolis: Hacket Publishing Company, 1987.

Singer, Peter. Animal Liberation 2nd ed. NY: New York Review of Books, 1990.

Sorenson, John About Canada: Animal Rights. Winnipeg: Fernwood Publishing, 2010.

Torres, Bob. Making a Killing: The Political Economy of Animal Rights. Oakland, CA: AK Press, 2007.

United Nations. Food and Agricultural Organization. The State of Food and Agriculture: Livestock in the Balance, 2009.

Welty, Jeff. "Humane Slaughter Laws." Law and Contemporary Problems 70 (2007): 175-206.

Winders, Bill and Dave Nibert. "Consuming the Surplus: Expanding "Meat" Consumption and Animal Oppression.” International Journal of Sociology and Social Policy 24 (2004): 76-96. 